\title{
Coffee and Arterial Hypertension
}

\author{
Stanisław Surma ${ }^{1,2}$ (D) Suzanne Oparil ${ }^{3}$ (D) \\ Accepted: 25 June 2021 / Published online: 9 August 2021 \\ (C) The Author(s) 2021
}

\begin{abstract}
Purpose of Review Coffee is a very popular drink and an estimated 2.25 billion cups worldwide are consumed daily. Such popularity of coffee makes it the most consumed drink next to water. Numerous studies have shown a beneficial effect of habitual and moderate coffee consumption on the functioning of the nervous, digestive, and cardiovascular systems, as well as on kidney function. Taking into account the very high prevalence of arterial hypertension in the world ( $31.1 \%$ of adults), much controversy has been raised about the influence of coffee consumption on blood pressure and the risk of arterial hypertension. Moreover, there have been extensive discussions about the safety of coffee consumption for hypertensive persons.

Recent Findings There are over 1000 chemical compounds in coffee. The best characterized of these are caffeine, chlorogenic acid, trigonelline, kahweol, cafestol, ferulic acid, and melanoidins. These compounds have bidirectional influences on blood pressure regulation. The results of numerous studies and meta-analyses indicate that moderate and habitual coffee consumption does not increase and may even reduce the risk of developing arterial hypertension. Conversely, occasional coffee consumption has hypertensinogenic effects. Moderate habitual coffee consumption in hypertensive persons does not appear to increase the risk of uncontrolled blood pressure and may even reduce the risk of death from any cause.

Summary Moderate and habitual consumption of coffee (1--3 cups / day) does not adversely affect blood pressure in most people, including those with arterial hypertension.
\end{abstract}

Keywords Coffee $\cdot$ Caffeine $\cdot$ Blood pressure $\cdot$ Arterial hypertension

\section{Introduction}

Coffee is the most consumed drink for humans next to water. According to the National Coffee Association USA, about 2.25 billion cups are drunk worldwide every day, totaling about 500 billion cups/year [1]. The

This article is part of the Topical Collection on Nutrition and Hypertension

Stanisław Surma

stanislaw.surma@med.sum.edu.pl

Suzanne Oparil

soparil@uabmc.edu

1 Faculty of Medical Sciences in Katowice, Medical Univeristy of Silesia in Katowice, Medyków 18, 40-752 Katowice, Poland

2 Club of Young Hypertensiologists, Polish Society of Hypertension, Warsaw, Poland

3 Department of Medicine, School of Medicine, University of Alabama at Brimingham, Brimingham, AL, USA available data indicate that the inhabitants of Finland consume the most coffee-on average over $10 \mathrm{~kg}$ per capita/ year [2]. In the USA and Poland, coffee consumption is $4.4 \mathrm{~kg}$ and over $3 \mathrm{~kg}$ per capita/year, respectively [2]. Results of numerous studies indicate beneficial effects of regular moderate coffee consumption on the nervous, cardiovascular (CV), and digestive systems, as well as on kidney function [3-7]. Recent research findings indicate that regular consumption of 2-3 cups of coffee a day reduces the risk of nonfatal and fatal $\mathrm{CV}$ diseases, type 2 diabetes, endometrial cancer, and melanoma and nonmelanoma skin cancer in the US population [8]. There are reviews of the literature that summarize the knowledge about the impact of coffee consumption on global health [9]. In contrast, the effects of coffee consumption on blood pressure (BP) and the risk of arterial hypertension are controversial. Given the very high prevalence of arterial hypertension (31.1\% of adults worldwide) [10] and the significant influence of diet on its pathogenesis, this article reviews the impact of coffee consumption on the risk of its occurrence. 


\section{Biologically Active Compounds in Coffee and Their Effects on BP}

It is estimated that there are over 1000 chemical compounds in coffee [9]. The composition of coffee depends on many factors, including the type of coffee (e.g., Coffea arabica, Coffea canephora, Coffea liberica) (Table 1), the method of production (wet, dry, semi-dry/semi-wet, and bio-processing), and the method of preparation (e.g., traditional coffee, espresso). Pre-harvest factors (e.g., sunlight) and post-harvest factors (e.g., method of processing coffee beans) account for approximately $40 \%$ and $60 \%$ of the organoleptic (being perceivable by the senses, such as smell, appearance, taste, and touch), physical, and biochemical properties of coffee, respectively $[5,9,11-13]$.

The most common chemical compounds in coffee are caffeine, chlorogenic acid, trigonelline, kahweol, and cafestol (Figure 1) [3]. Less abundant compounds found in coffee include mannose, polysaccharide chains of galactose, melanoidins, flavonoids, catechins, anthocyanins, ferulic acid, caffeic acid, p-coumaric acid, and tocopherols [9, 11]. Since it is likely that not all of the chemical compounds present in coffee have been identified, and that the mechanisms of action of most of the identified compounds are not yet fully understood, the biological properties of coffee are currently attributed to the effects of the best described compounds, such as caffeine, chlorogenic acid, trigonelline, cafestol, and kahweol, as well as ferulic acid. Figure 2 summarizes the potential biochemical mechanisms of the influence of coffee on BP.

The biologically active compounds of coffee have many mechanisms of action. Caffeine can both increase and decrease $B P$ by antagonizing the adenosine receptors $A_{1} R$, $\mathrm{A}_{2 \mathrm{~A}} \mathrm{R}$, and $\mathrm{A}_{2 \mathrm{~B}} \mathrm{R}$, thus altering total peripheral resistance, diuresis, and heart rate. Regular consumption of 2-3 cups of coffee per day leads to the development of tolerance to caffeine. This tolerance explains the lack of a pressor effect of caffeine in people who habitually consume coffee [19]. Other compounds found in coffee, such as chlorogenic acid,

Table 1 Characteristics of Coffea arabica, Coffea robusta, and Coffea liberica [14-16]

\begin{tabular}{|c|c|c|c|}
\hline \multirow[t]{2}{*}{ Characteristics } & \multicolumn{3}{|c|}{ Type of coffee } \\
\hline & Coffea arabica & Coffea canephora & Coffea liberica \\
\hline $\begin{array}{l}\text { The main place of } \\
\text { cultivation }\end{array}$ & $\begin{array}{c}\text { Brazil, Central } \\
\text { America and Africa }\end{array}$ & $\begin{array}{l}\text { Vietnam, Brazil, } \\
\text { Indonesia and Africa }\end{array}$ & $\begin{array}{l}\text { Malaysia, some } \\
\text { regions of the } \\
\text { Philippines } \\
\text { and Africa (Liberia) }\end{array}$ \\
\hline \multicolumn{4}{|l|}{ Bean } \\
\hline $\begin{array}{l}\text { Participation } \\
\text { in the global coffee } \\
\text { market }\end{array}$ & $64 \%$ & $35 \%$ & $1 \%$ \\
\hline $\begin{array}{l}\text { The aroma of the } \\
\text { coffee }\end{array}$ & ++ & +++ & + \\
\hline \multicolumn{4}{|c|}{ Mean concentration of biological components $[\mathrm{g} / 100 \mathrm{~g}]$} \\
\hline Caffeine & 1.61 & 2.26 & 1.23 \\
\hline Water & $8-12$ & $8-12$ & 11 \\
\hline Protein & 9.8 & 9.5 & 14 \\
\hline $\begin{array}{l}\text { Sucrose + reducing } \\
\text { sugars }\end{array}$ & 8.1 & 4.4 & 8 \\
\hline Polysaccharides & 49.8 & 54.4 & 42 \\
\hline Lipids & 16.2 & 10 & 12 \\
\hline Chlorogenic acid & 6.5 & 10 & 7 \\
\hline Minerals & 4.2 & 4.4 & 4 \\
\hline
\end{tabular}


Figure 1 The main chemical compounds found in traditional coffee and espresso in terms of concentration and total amount in the usual serving sizes [3]

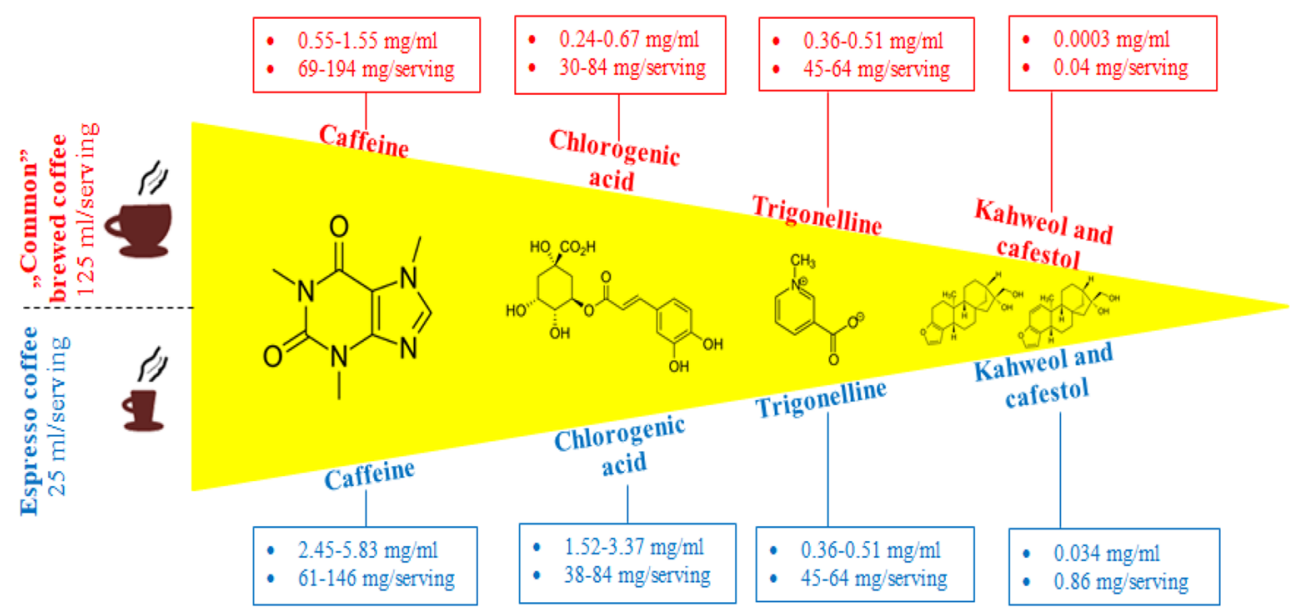

trigonelline, melanoidins, and ferulic acid, have antihypertensive effects mediated by reducing angiotensin converting enzyme activity, protecting the vessels against oxidative stress, and increasing the bioavailability of nitric oxide [17-24].

Habitual coffee consumption may also affect BP by altering the composition of the gut microbiota. A study by González et al. assessed the impact of habitual coffee consumption (up to $45 \mathrm{ml} /$ day and $45-500 \mathrm{ml} /$ day) on the composition of the gut microbiota in a population of 147 healthy normotensive persons. Coffee consumption has been shown to be associated with an increase in the level of Bacteroides [25]. Two groups of coffee-derived (poly)phenols, methoxyphenols and alkylphenols, as well as caffeine, were positively associated with gut microbiota Bacteroides

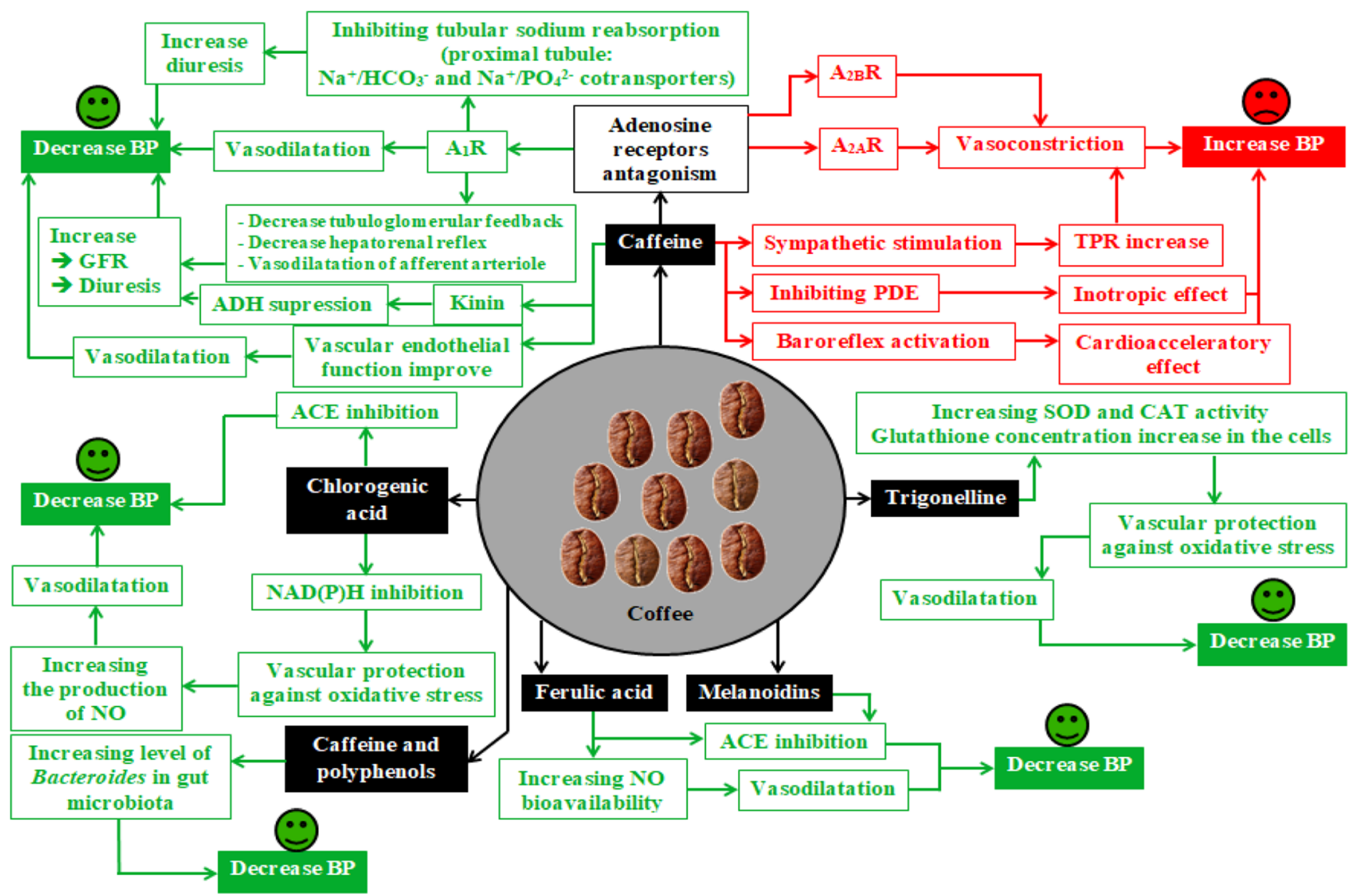

Figure 2 Effects of major compounds derived from coffee on BP [17-26]. $A_{1} R$ - adenosine $A_{1}$ receptor; $A_{2 A} R$-adenosine $A_{2 A}$ receptor; $\mathrm{A}_{2 \mathrm{~B}} \mathrm{R}$ - adenosine $\mathrm{A}_{2 \mathrm{~B}}$ receptor; $\mathrm{GFR}$ - glomerular filtration rate; $\mathrm{PDE}$ phosphodiesterase; ACE — angiotensin-converting enzyme; TPR — total peripheral resistance; SOD — superoxide dismutase; CAT—catalase; $\mathrm{BP}$ - blood pressure; $\mathrm{NO}$ - nitric oxide; $\mathrm{NAD}(\mathrm{P}) \mathrm{H}$ - nicotinamide adenine dinucleotide phosphate oxidase 
levels [25]. Since the level of Bacteroides in gut microbiota is negatively associated with systolic and diastolic BP [26], habitual coffee consumption may lower BP via increasing the level of Bacteroides in gut microbiota.

In summary, coffee contains many biologically active compounds, and the content of these compounds varies depending on the type of coffee, the way it is prepared, and many other factors, which have been described above. Compounds contained in coffee, such as chlorogenic acid, ferulic acid, melanoidins, and trigonelline, have antihypertensive effects.

\section{Coffee Consumption and the Risk of All-Cause and CVD Mortality}

A recent study by Torres-Callado et al. assessed the effects of coffee consumption on all-cause, cardiovascular, and cancer mortality. The study included 1567 people who were followed for 18 years. Consumption of $>1$ cup of coffee/day was associated with a reduced risk of all-cause mortality ( $\mathrm{HR}=0.56$; $95 \%$ CI: $0.41-0.77)$ and cancer ( $[\mathrm{HR}=0.41 ; 95 \% \mathrm{CI}$ : $0.20-0.86)$ but had no effect of CVD mortality (HR $=0.71 ; 95 \%$ CI: $0.41-1.20$ ) [27]. In contrast, a meta-analysis by Di Maso et al. of 26 prospective studies showed that consumption of 3-4 cups of coffee/ day significantly reduced risk of developing or dying from CVD ( $\mathrm{RR}=0.90 ; 95 \%$ CI: $0.84-0.96)$ [8]. In a study by Tverdal et al. of 508,747 persons followed for 20 years, coffee consumption (filtered and unfiltered) was significantly associated with $21 \%$ and $16 \%$ reductions in risk of all-cause mortality in men and women, respectively. Subgroup analysis showed that coffee consumption was significantly associated with a $28 \%$ reduction in the risk of death from CVD in women (women: $\mathrm{HR}=0.72 ; 95 \%$ CI: $0.61-0.85$ but not in men: $\mathrm{HR}=0.93 ; 95 \%$ CI: $0.83-1.04)$. In men, only the consumption of filtered coffee was associated with a significant $12 \%$ reduction in the risk of death due to CVD (HR $=0.88 ; 95 \%$ CI: $0.81-0.96$ ) [28]. A meta-analysis of 31 studies by Grosso et al. showed that consumption of up to 4 cups of coffee a day was associated with a $14 \%$ reduction in the risk of all-cause mortality ( $R R=0.86 ; 95 \%$ CI: $0.82-0.89)$ and a $15 \%$ reduction in the risk of CVD mortality $(\mathrm{RR}=0.85 ; 95 \% \mathrm{CI}$ : 0.77-0.93). In addition, non-smokers derived greater benefit from consuming coffee than those who smoked [29].

The effect of coffee consumption on the risk of mortality in patients with pre-existing CVD has also been examined. A study by Teramoto et al. of 46,213 patients, including those with and without an antecedent heart attack or stroke, who were followed for 18.5 years showed a significant $14 \%$ reduction in the risk of death in those without prior myocardial infarction or stroke who consumed 1-6 cups of coffee/day $(\mathrm{HR}=0.86 ; 95 \%$ CI: 0.82-0.91). There was no significant effect of coffee consumption on the risk of death in patients with a stroke history $(\mathrm{HR}=1.31 ; 95 \%$ CI: $0.94-1.82)$, but there was a significant $31 \%$ reduction in risk of death in patients with a history of myocardial infarction who consumed $1-6$ cups of coffee/day (HR $=0.69$; 95\% CI: 0.53 0.91) [30].

Polymorphisms in the gene encoding the enzyme CYP1A2 involved in caffeine metabolism may influence the biological effects of coffee consumption. Increased risk of myocardial infarction and arterial hypertension has been found in individuals who carry a functional variant of cytochrome P450 1A2 (CYP1A2), which makes them less effective in metabolizing caffeine [31-33]. A study by Zhou and Hyppönen that included data from 347,077 individuals in the UK Biobank showed that consuming 1-6 cups of coffee a day was not significantly associated with risk of CVD. Moreover, an analysis of CYP1A2 gene polymorphisms (CYP1A2 AA-fast caffeine metabolism versus CYP1A2 CA + CC - slow caffeine metabolism) showed that polymorphisms in the gene did not affect the observed effects of coffee consumption on CVD risk ( $\mathrm{p} \geq$ $0.53)$ [34].

In summary, coffee consumption can reduce the risk of allcause and CVD mortality, including in patients after a myocardial infarction. Factors such as smoking or the way coffee is prepared have a significant impact on the observed effect of coffee consumption on human health. Importantly, the biochemical mechanisms of the beneficial effects of coffee consumption in reducing all-cause mortality are not well understood. A recent systematic review of 17 randomized clinical trials by Daneschvar et al. found a lack of convincing evidence that an anti-inflammatory effect of coffee is a major contributing factor to the lower all-cause mortality reported in observational studies of the effects of coffee consumption on CVD risk [35].

\section{Coffee Consumption and BP and Risk of Arterial Hypertension-Results of Clinical Studies and Meta-analyses}

The effects of coffee consumption on BP and risk of hypertension have been examined in many studies and meta-analyses, as summarized in Table 2. Results of these studies and meta-analyzes indicate that the habitual (regular) consumption of 2-3 cups of coffee a day does not alter the risk of arterial hypertension in most people, especially in women and nonsmokers. Conversely, non-habitual (irregular; occasional) coffee consumption is associated with an increase in BP and may increase the risk of arterial hypertension.

\section{Safety of Coffee Consumption by Patients with Arterial Hypertension}

The meta-analysis of Mesas et al. analyzed the effects of a single ingestion of 200-300 mg of caffeine (5 studies) and 
Table 2 Effect of habitual and non-habitual coffee consumption on blood pressure and the risk of arterial hypertension — summary of studies results and meta-analysis

\begin{tabular}{|c|c|c|c|c|c|}
\hline Author & Year & Type of study & Samplesize & Results & $\begin{array}{l}\text { Effect on blood pressure } \\
\text { or risk of hypertension }\end{array}$ \\
\hline \multicolumn{6}{|c|}{ Habitual coffee consumption } \\
\hline $\begin{array}{l}\text { Miranda A. } \\
\text { et al. } \\
\text { [36] }\end{array}$ & 2021 & Cohort & 8780 persons & $\begin{array}{l}\text { Over the period of } 3.9 \text { years of follow-up, } \\
\text { hypertension developed in } 1285 \text { people. The effect of } \\
\text { coffee on the risk of hypertension was related to the } \\
\text { number of cups consumed: } \\
\checkmark \leq 1 \text { cup } \rightarrow \text { [RR }=0,86 ; 95 \% \text { CI } 0.67-1.10] \\
\checkmark \quad 1-3 \text { cups } \rightarrow-18 \% \text { [RR }=0.82 ; 95 \% \text { CI } 0.68-0.97] \\
\checkmark>3 \text { cups } \rightarrow \text { [RR }=0.85 ; 95 \% \text { CI: } 0.70-1.04]\end{array}$ & $\begin{array}{c}\text { beneficial effect only in } \\
\text { never-smokers }\end{array}$ \\
\hline $\begin{array}{l}\text { Ghavami H. } \\
\text { et al. } \\
\text { [37] }\end{array}$ & 2021 & $\begin{array}{l}\text { Cross- } \\
\text { sectional }\end{array}$ & $\begin{array}{l}300 \text { subjects } \\
\text { with DMT2 }\end{array}$ & $\begin{array}{l}\text { Consumption of }<1 \text { to }>3 \text { cups of coffee / day was } \\
\text { significantly associated with a reduction in diastolic } \\
\text { BP }[r=-0.134 ; p=0.022] \text { and had no significant } \\
\text { effect on systolic BP }[r=-0.014 ; p=0.809]\end{array}$ & \\
\hline $\begin{array}{l}\text { van Oort S. } \\
\text { et al. } \\
\text { [38] }\end{array}$ & 2020 & $\begin{array}{l}\text { Mendelian } \\
\text { randomization }\end{array}$ & $\begin{array}{l}553225 \\
\text { subjects }\end{array}$ & $\begin{array}{l}\text { Coffee consumption was not significantly associated } \\
\text { with the risk of hypertension [OR }=1.04 ; 95 \% \mathrm{CI} \text { : } \\
0.90-1.20]\end{array}$ & \\
\hline $\begin{array}{l}\text { Kim J. } \\
\text { et al. } \\
\text { [39] }\end{array}$ & 2020 & Meta-analysis & 4 studies & $\begin{array}{l}\text { Coffee consumption versus not consumption } \\
10 \% \text { reduction the risk of hypertension } \\
{[\mathrm{OR}=0.90 ; 95 \% \text { CI: } 0.83-0.98]}\end{array}$ & \\
\hline $\begin{array}{l}\text { D'Elia L. } \\
\text { et al. } \\
{[40]}\end{array}$ & 2019 & Meta-analysis & 4 studies & 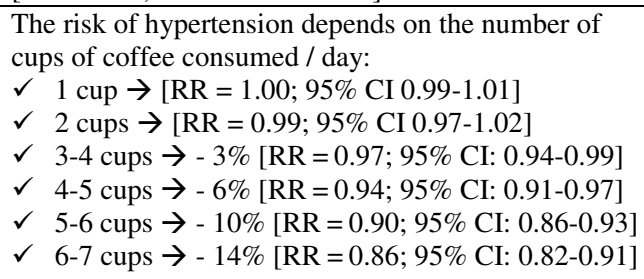 & \\
\hline
\end{tabular}

\begin{tabular}{|c|c|c|c|c|c|}
\hline $\begin{array}{l}\text { Miranda A. } \\
\text { et al. } \\
{[41]}\end{array}$ & 2019 & $\begin{array}{l}\text { Preventive - } \\
\text { genetics }\end{array}$ & 533 subjects & $\begin{array}{l}\text { Coffee consumption by people predisposed to the } \\
\text { development of hypertension [polymorphisms: } \\
\text { CYP1A1 / CYP1A2 (rs2470893, rs2472297); CPLX3 } \\
\text { / ULK3 (rs6495122); MTHFR (rs17367504)] has been } \\
\text { associated with an increase in BP }\end{array}$ & 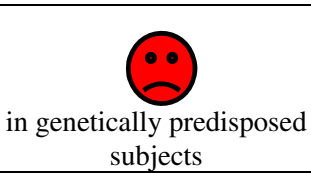 \\
\hline $\begin{array}{l}\text { Navarro A. } \\
\text { et al. } \\
{[42]}\end{array}$ & 2019 & $\begin{array}{l}\text { Prospective } \\
\text { cohort }\end{array}$ & 13374 subjects & $\begin{array}{l}\text { During } 9.1 \text { years of follow-up, it was found that } \\
\text { coffee consumption by women was associated with a } \\
\text { reduction in the risk of hypertension by: } \\
\checkmark \quad<1 \text { cup } \rightarrow-28 \% \text { [HR }=0.72 ; 95 \% \text { CI: } 0.57-0.92 \text { ] } \\
\checkmark \quad 4 \text { cups } \rightarrow-26 \% \text { [HR }=0.74 ; 95 \% \text { CI: } 0.60-0.92 \text { ] } \\
\checkmark \quad 6 \text { cups } \rightarrow-26 \% \text { [HR }=0.74 ; 95 \% \text { CI: } 0.61-0.91] \\
\text { Coffee consumption was not significantly associated } \\
\text { with the risk of hypertension in men }\end{array}$ & $\begin{array}{c}\text { beneficial effect only in } \\
\text { women }\end{array}$ \\
\hline $\begin{array}{l}\text { Xie C. } \\
\text { et al. } \\
{[43]}\end{array}$ & 2018 & Meta-analysis & 10 studies & $\begin{array}{l}\text { Reduction of the risk of hypertension depending on } \\
\text { the number of cups of coffee consumed / day: } \\
\checkmark \quad 2 \text { cups } \rightarrow-3 \% \text { [RR }=0.97 ; 95 \% \text { CI: } 0.95-0.99] \\
\checkmark \quad 4 \text { cups } \rightarrow-5 \% \text { [RR }=0.95 ; 95 \% \text { CI: } 0.91-0.99] \\
\checkmark \quad 6 \text { cups } \rightarrow-8 \% \text { [RR }=0.92 ; 95 \% \text { CI: } 0.87-0.98] \\
\checkmark \quad 8 \text { cups } \rightarrow-10 \% \text { [RR }=0.90 ; 95 \% \text { CI: } 0.83-0.97] \\
\text { The risk of hypertension was reduced by } 2 \% \text { [RR }= \\
0.98 ; 95 \% \text { CI: } 0.98-0.99] \text { for each increase in coffee } \\
\text { consumption by one cup per day }\end{array}$ & \\
\hline $\begin{array}{l}\text { Poole R. } \\
\text { et al. } \\
{[44]}\end{array}$ & 2017 & Meta-analysis & $\begin{array}{l}1246388 \\
\text { subjects }\end{array}$ & $\begin{array}{l}\text { Coffee consumption does not significantly reduce BP } \\
\text { [systolic: }-0.66 \mathrm{mmHg} ; 95 \% \mathrm{CI}:-2.71 \text { to } 1.39 \mathrm{mmHg} \\
\text { and diastolic: }-0.45 \mathrm{mmHg} \text {; } 95 \% \mathrm{CI}:-1.51 \text { to } 0.61 \\
\mathrm{mmHg} \text { ] and did not affect the risk of hypertension } \\
\text { [OR }=1.03 ; 95 \% \mathrm{CI}: 0.98-1.08 \text { ] }\end{array}$ & \\
\hline
\end{tabular}




\begin{tabular}{|c|c|c|c|c|c|}
\hline $\begin{array}{l}\text { Grosso G. } \\
\text { et al. } \\
{[45]}\end{array}$ & 2017 & Meta-analysis & 7 studies & $\begin{array}{l}\text { The analysis of the entire group did not show a } \\
\text { significant effect of coffee consumption on the risk of } \\
\text { hypertension. Significance was shown among women: } \\
\checkmark \quad 1 \text { cup } \rightarrow \text { [RR }=1.00 \text {; } 95 \% \text { CI: } 0.97-1.03 \text { ] } \\
\checkmark \quad 2 \text { cups } \rightarrow \text { [RR }=1.00 ; 95 \% \text { CI: } 0.94-1.05] \\
\checkmark \quad 3 \text { cups } \rightarrow \text { [RR }=0.98 ; 95 \% \text { CI: } 0.92-1.04] \\
\checkmark \quad 4 \text { cups } \rightarrow-5 \% \text { [RR }=0.95 ; 95 \% \text { CI: } 0.91-0.99] \\
\checkmark \quad 5 \text { cups } \rightarrow-8 \% \text { [RR }=0.92 ; 95 \% \text { CI: } 0.88-0.95] \\
\checkmark \quad 6 \text { cups } \rightarrow-12 \% \text { [RR }=0.88 ; 95 \% \text { CI: } 0.84-0.94] \\
\checkmark \quad 7 \text { cups } \rightarrow-15 \% \text { [RR }=0.85 ; 95 \% \text { CI: } 0.78-0.93]\end{array}$ & (@) \\
\hline $\begin{array}{l}\text { Rhee J. } \\
\text { et al. } \\
\text { [46] }\end{array}$ & 2016 & Prospective & $\begin{array}{c}29985 \\
\text { postmenpausal } \\
\text { women }\end{array}$ & $\begin{array}{l}\text { Consumption of } 1,2-3 \text { and } \nabla 4 \text { cups of coffee / day } \\
\text { did not significantly affect the risk of arterial } \\
\text { hypertension }[p=0.51]\end{array}$ & \\
\hline $\begin{array}{l}\text { Grosso G. } \\
\text { et al. } \\
{[47]}\end{array}$ & 2016 & Cohort & $\begin{array}{c}2725 \\
\text { Polish subjects }\end{array}$ & $\begin{array}{l}\text { The effect on the risk of hypertension was related to } \\
\text { the number of cups of coffee consumed: } \\
\checkmark \quad 1-2 \text { cups } \rightarrow \text { [OR }=0.86 ; 95 \% \text { CI: } 0.68-1.07] \\
\checkmark \quad 3-4 \text { cups } \rightarrow-25 \% \text { [OR }=0.75 ; 95 \% \text { CI: } 0.58- \\
\quad 0.95] \\
\checkmark>4 \text { cups } \rightarrow \text { [OR }=1.58 ; 95 \% \text { CI: } 0.85-3.64]\end{array}$ & $\bigodot \begin{array}{c}\bullet \\
\text { beneficial effect only in } \\
\text { non-smoking subjects }\end{array}$ \\
\hline $\begin{array}{l}\text { Steffen M. } \\
\text { et al. } \\
{[48]}\end{array}$ & 2012 & Meta-analysis & 15 studies & $\begin{array}{l}\text { Coffee consumption does not significantly reduce BP } \\
\text { [SBP }-0.55 \mathrm{mmHg} \text {; } 95 \% \mathrm{CI}:-2.46 \text { to } 1.36 \mathrm{mmHg} \text { and } \\
\text { DBP }-0.45 \mathrm{mmHg} \text {; } 95 \% \mathrm{CI}:-1.52 \text { to } 0.61 \mathrm{mmHg} \text { and } \\
\text { was not significantly associated with the risk of } \\
\text { hypertension [RR }=1.03 ; 95 \% \mathrm{CI}: 0.98-1.08]\end{array}$ & \\
\hline
\end{tabular}

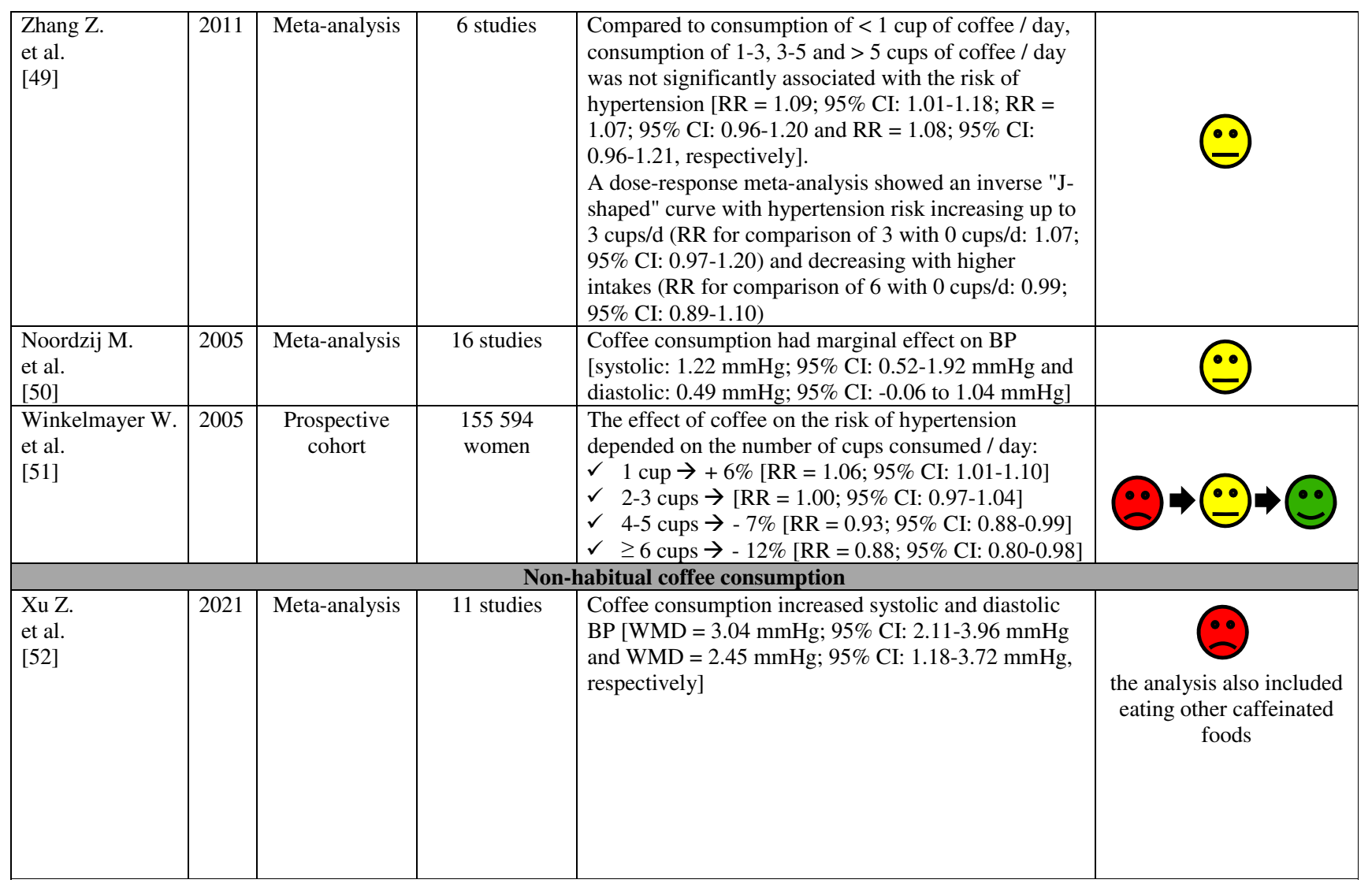




\begin{tabular}{|c|c|c|c|c|c|c|}
\hline $\begin{array}{l}\text { Zimmermann- } \\
\text { Viehoff F. } \\
\text { et al. } \\
\text { [53] }\end{array}$ & 2016 & $\begin{array}{l}\text { Randomized } \\
\text { crossover }\end{array}$ & $\begin{array}{l}38 \text { habitual } \\
\text { and } 39 \text { non- } \\
\text { habitual coffee } \\
\text { consumers }\end{array}$ & $\begin{array}{l}\text { The consumption of espresso did not significantly } \\
\text { affect BP in people who are habitually consuming } \\
\text { coffee. In occasional coffee drinkers, the consumption } \\
\text { of espresso increased BP }\end{array}$ & $\bigodot_{\substack{\text { Habitual } \\
\text { drinkers }}}^{\bullet 0}$ & $\begin{array}{c}\text { Non- } \\
\text { habitual } \\
\text { drinkers }\end{array}$ \\
\hline $\begin{array}{l}\text { Teng C. } \\
\text { et al. } \\
\text { [54] }\end{array}$ & 2016 & $\begin{array}{l}\text { Randomized } \\
\text { controlled }\end{array}$ & $\begin{array}{l}104 \text { subjects } \\
\text { (22 daily } \\
\text { coffee } \\
\text { drinkers) }\end{array}$ & $\begin{array}{l}\text { Coffee consumption did not significantly increase BP } \\
\text { [systolic: } \mathrm{p}=0.05 \text {; diastolic: } \mathrm{p}=0.64] \text {. } \\
\text { Non-habitual coffee drinkers were more likely to } \\
\text { show an increase in systolic BP }\end{array}$ & & \\
\hline $\begin{array}{l}\text { Hara A. } \\
\text { et al. } \\
{[55]}\end{array}$ & 2014 & $\begin{array}{c}\text { Randomized } \\
\text { controlled }\end{array}$ & $\begin{array}{c}84 \text { non- } \\
\text { habitual and } \\
52 \text { habitual } \\
\text { coffee } \\
\text { consumers }\end{array}$ & $\begin{array}{l}\text { Coffee consumption by non-habitual coffee drinkers } \\
\text { was associated with increases in systolic and diastolic } \\
\text { BP [systolic: } 109.3 \pm 1.8 \mathrm{mmHg} \text { versus } 111.3 \pm 2.1 \\
\mathrm{mmHg} \text {; diastolic: } 65.8 \pm 1.3 \mathrm{mmHg} \text { versus } 65.6 \pm 1.2 \\
\mathrm{mmHg} \text { ]. } \\
\text { In habitual coffee drinkers, coffee consumption was } \\
\text { associated with a slight decrease (compared to } \\
\text { placebo) [systolic: } 115.5 \pm 3.3 \mathrm{mmHg} \text { versus } 112.1 \pm \\
2.3 \mathrm{mmHg} \text {; diastolic: } 68.3 \pm 1.9 \mathrm{mmHg} \text { versus } 66.9 \pm \\
1.3 \mathrm{mmHg} \text { ] }\end{array}$ & $\begin{array}{l}\text { Habitual } \\
\text { drinkers }\end{array}$ & $\begin{array}{l}\text { Non- } \\
\text { habitual } \\
\text { drinkers }\end{array}$ \\
\hline $\begin{array}{l}\text { Corti R. } \\
\text { et al. } \\
{[56]}\end{array}$ & 2002 & $\begin{array}{l}\text { Placebo } \\
\text { controlled }\end{array}$ & $\begin{array}{l}6 \text { habitual and } \\
9 \text { non-habitual } \\
\text { coffee drinkers }\end{array}$ & $\begin{array}{l}\text { Coffee drinking increased BP only in non-habitual } \\
\text { drinkers [p }<0.001] \text {. Interestingly, both groups } \\
\text { showed a comparable increase in muscle sympathetic } \\
\text { nervous activity and plasma caffeine levels }\end{array}$ & $\begin{array}{l}\bigodot_{\text {Habitual }}^{(\infty)} \\
\text { drinkers }\end{array}$ & $\begin{array}{l}\text { Non- } \\
\text { habitual } \\
\text { drinkers }\end{array}$ \\
\hline \multicolumn{7}{|c|}{$\begin{array}{ll}\text { Legend: } \\
\checkmark \text { the studies are listed in chronological order }\end{array}$} \\
\hline
\end{tabular}

Table 3 Summary of societies' positions on the influence of coffee consumption on arterial hypertension, CVD, and overall health. $B P$ blood pressure, $C V D$ cardiovascular disease

Scientific society

Specific comment on effects References on $\mathrm{BP}$ or $\mathrm{CVD}$

International Society of Hypertension (2020)

Polish Society of Hypertension (2019)

European Society of Hypertension and European Society of Cardiology (2018)

American College of Cardiology, American Heart Association, and American Society of Hypertension (2017)
$>$ Moderate consumption of coffee is a healthy drink

$\gg$ Available research evidence, mostly of observational nature, does not indicate a higher risk of hypertension development or higher blood pressure values in people who regularly drink coffee

$>$ Caffeine has been shown to have an acute pressor effect

$>$ Coffee consumption is associated with cardiovascular benefits

$>$ Coffee use in patients with hypertension is associated with acute increases in BP

$>$ Long-term use of coffee is not associated with increased blood pressure or cardiovascular disease habitual coffee consumption (6 studies) on BP and CVD risk in patients with arterial hypertension. Ingestion of 200 $300 \mathrm{mg}$ of caffeine (1.5-2 cups of coffee) increased systolic BP by $8.14 \mathrm{mmHg}$ (95\% CI: $5.68-10.61 \mathrm{mmHg}$ ) and diastolic BP by $5.75 \mathrm{mmHg}$ (95\% CI: $4.09-7.41 \mathrm{mmHg}$ ). The duration of the BP effect was at least $3 \mathrm{~h}$. Studies of the longer-term effect (2 weeks) of coffee consumption showed no increase in BP. Habitual coffee consumption has not been shown to increase CVD risk in patients with arterial hypertension [57]. A study by Palatini et al. that analyzed the association of coffee consumption and CYP1A2 polymorphism with risk of impaired fasting glucose in hypertensive patients $(n=1180)$ also provided accurate data on coffee consumption and BP. There were no significant differences in 24-h BP between non-coffee drinkers and those consuming 1-3 and $>3$ cups of coffee/day (systolic BP: $130.9 \pm 10.4 \mathrm{mmHg}$ versus $131.0 \pm 10.8 \mathrm{mmHg}$ versus $131.8 \pm 12.0 \mathrm{mmHg}(\mathrm{p}=0.72)$; diastolic $\mathrm{BP}: 81.5$ $\pm 8.1 \mathrm{mmHg}$ versus $81.5 \pm 8.2 \mathrm{mmHg}$ versus $81.0 \pm 8.0 \mathrm{mmHg}$ $(\mathrm{p}=0.79))[58]$.

The HARVEST study enrolled 1,204 participants with arterial hypertension and followed them for 12.6 years. It showed that consumption of 1-3 cups of coffee per day was associated with a non-significant increase in the risk of CVD events ( $\mathrm{HR}=2.8 ; 95 \%$ CI: 1.0-7.9), while consumption of $\geq 4$ cups a day significantly increased the risk $(\mathrm{HR}=4.5 ; 95 \% \mathrm{CI}$ : 1.4-14.2) [59]. A study by Lopez-Garcia et al. examined the effect of habitual coffee consumption on the risk of uncontrolled 24-h BP (BP $\geq 130 / 80 \mathrm{mmHg}$ ) in elderly patients with 
arterial hypertension $(n=715)$. Persons who consumed between 1 and $>3$ cups of coffee a day had a higher risk of uncontrolled BP $(\mathrm{OR}=1.95$; $95 \% \mathrm{CI}: 1.15-3.30$ and $\mathrm{OR}=$ 2.55; 95\% CI: $1.28-5.09)$. Consumption of 2 cups of coffee/ day was not significantly associated with lack of BP control $(\mathrm{OR}=1.41$; 95\% CI: 0.75-2.68). Among women, no significant effect of coffee consumption (1,2, or $>3$ cups/day) on the risk of uncontrolled BP was found. Importantly, after taking into account smoking, the consumption of 1,2 , and $>3$ cups of coffee/day in never smokers was not significantly associated with risk of uncontrolling BP. Further, coffee consumption was not significantly associated with the risk of a non-dipper BP profile in either women or men [60].

In summary, the results of these studies indicate that the consumption of 1-3 cups of coffee/day in most patients with arterial hypertension does not increase the risk of uncontrolled $\mathrm{BP}$, including the occurrence of the non-dipper BP profile, or the risk of a CVD event.

\section{Factors Limiting the Interpretation of Findings of Studies and Meta-analyses}

An important limitation of studies of the impact of coffee consumption on human health is the lack of information about what kind of coffee was consumed by their participants (type, blend, country of origin, type of grains, preparation method, additives milk and/or sugar, as well as the different definition of a cup). In the systematic review by Daneschvar et al., it was found that consumption of boiled coffee increased the serum concentration of total cholesterol, low-density lipoprotein, and apolipoprotein B. This effect was not observed in people who consumed filtered coffee [35]. Another significant limitation is the lack of detail about the spectrum of CVD risk factors in study participants. Further, lack of information about the influence of the participants' diet, as well as polymorphisms of many genes encoding enzymes involved in the metabolism of biochemical components of coffee, as well as their biological actions (e.g., activation of adenosine receptors) is another limitation of published studies. These polymorphisms may differ between the races of study participants, possibly resulting in differential sensitivity to coffee and thus the occurrence of various biological effects after its consumption [61-63]. Recently, an important role of epigenetics has been cited to account for the different effects of coffee observed in various studies since coffee consumption is associated with different levels of DNA methylation in many $\mathrm{CpG}$ sites, which can lead to a change in the expression of various genes. Varying levels of $\mathrm{CpG}$ methylation may thus explain the different biological effects of coffee consumption observed in various studies [64,
65]. The variable concentrations of biologically active compounds other than caffeine in coffee may also explain the discrepancies observed in some studies and limit the possibility of their interpretation. Moreover, most of the metaanalyses were based on the results of observational studies, which allows only the formulation of hypotheses and not the assessment of cause-and-effect relationships. In addition, there is growing evidence that coffee and smoking can have an interactive effect on blood pressure, as it can have a significant effect on the results of studies. Researchers from the HARVEST Study described this phenomenon as early as 1995 [66]. Importantly, in some studies, no differences in biological effects were observed between natural coffee and decaffeinated coffee, indicating a significant role for constituents other than caffeine.

\section{Review of Clinical Recommendations and Summary}

Table 3 summarizes the opinions of various hypertension/ cardiology societies on the impact of coffee consumption on the risk of arterial hypertension.

Coffee is a widely consumed drink all over the world. Coffee contains many biologically active compounds which result in multidirectional effects on the regulation of BP. Regular moderate (1-3 cups of coffee/day) coffee consumption may reduce BP and the risk of developing hypertension, as well as the risk of death from any cause. Habitual and moderate (1-3 cups of coffee/day) coffee consumption likely does not increase the risk of uncontrolled BP and does not disturb the circadian BP profile in hypertensive patients.

\section{Declarations}

Conflict of Interest The authors declare that they no conflict of interest.

Human and Animal Rights and Informed Consent This article does not contain any studies with human or animal subjects performed by any of the authors.

Open Access This article is licensed under a Creative Commons Attribution 4.0 International License, which permits use, sharing, adaptation, distribution and reproduction in any medium or format, as long as you give appropriate credit to the original author(s) and the source, provide a link to the Creative Commons licence, and indicate if changes were made. The images or other third party material in this article are included in the article's Creative Commons licence, unless indicated otherwise in a credit line to the material. If material is not included in the article's Creative Commons licence and your intended use is not permitted by statutory regulation or exceeds the permitted use, you will need to obtain permission directly from the copyright holder. To view a copy of this licence, visit http://creativecommons.org/licenses/by/4.0/. 


\section{References}

Papers of particular interest, published recently, have been highlighted as:

- Of importance

•- Of major importance

1. https://www.ncausa.org/(access: $7^{\text {th }}$, June, 2021)

2. https://anamsuperlink.blogspot.com/2017/09/secret-billions-ofpeople-drink-cofee.html(access: $7^{\text {th }}$, June, 2021)

3. Romualdo G, Rocha A, Vinken M, Cogliati B, Moreno F, Chaves $\mathrm{M}$, et al. Drinking for protection? Epidemiological and experimental evidence on the beneficial effects of coffee or major coffee compounds against gastrointestinal and liver carcinogenesis. Food Res Int. 2019;123:567-89. https://doi.org/10.1016/j.foodres.2019. 05.029 .

4. Surma S, Narkiewicz K. Coffee and the risk of arterial hypertension and other cardiovascular diseases. Choroby Serca i Naczyń. 2020;17:55-64. https://doi.org/10.5603/ChSiN.2020.0001 [article in Polish].

5. de Melo PG, de Carvalho ND, Magalhães Júnior A, do Prado F, Pagnoncelli M, Karp S, et al. Chemical composition and health properties of coffee and coffee by-products. Adv Food Nutr Res. 2020;91:65-96. https://doi.org/10.1016/bs.afnr.2019.10.002.

6. Surma S, Kokot F. Influence of chronic coffee consumption on the risk of kidney and other organ diseases. Review of the literature and clinical studies. Forum Nefrologiczne. 2021;14(3): accepted for publication [article in Polish].

7. Surma S, Romańczyk M, Fojcik J, Krzystanek M. Coffee: drug, stimulant substance and narcotic. Psychiatria. 2020;17:237-46. https://doi.org/10.5603/PSYCH.a2020.0031. [article in Polish]

8.• Di Maso M, Boffetta P, Negri E, La Vecchia C, Bravi F. Caffeinated coffee consumption and health outcomes in the US population: a dose-response meta-analysis and estimation of disease cases and deaths avoided. Adv Nutr. 2021. https://doi.org/10. 1093/advances/nmaa177. Meta-analysis showing the healthpromoting properties of coffee consumption (reduction of the risk of disease/death from cardiovascular causes, reduction of the risk of type 2 diabetes, endometrial cancer, and melanoma and non-melanoma skin cancer).

9. De Mejia G, Ramirez-Mares M. Impact of caffeine and coffee on our health. Trends Endocrinol Metab. 2014;25:489-92. https://doi. org/10.1016/j.tem.2014.07.003.

10. Mills K, Stefanescu A, He J. The global epidemiology of hypertension. Nat Rev Nephrol. 2020;16(4):223-37. https://doi.org/10. 1038/s41581-019-0244-2.

11. Wintgens J. Factors influencing the quality of green coffee. In: Coffee: Growing, Processing, Sustainable Production. A Guidebook for Growers, Processors, Traders and Researchers. Weinheim, Germany: Wiley-VCH; 2009. p. 797-817.

12. Nieber K. The impact of coffee on health. Planta Med. 2017;83: 1256-63. https://doi.org/10.1055/s-0043-115007.

13. Eun J-B, Jo M-Y, Im J-S. Physicochemical characteristics of coffee extracts using different extraction methods. Korean J Food Sci Technol. 2014;46:723-8. https://doi.org/10.9721/KJFST.2014.46. 6.723.

14. Rao N, Fuller M, Grim M. Physiochemical characteristics of hot and cold brew coffee chemistry: the effects of roast level and brewing temperature on compound extraction. Foods. 2020;9:902. https://doi.org/10.3390/foods9070902.

15. Keng-Chee SA, Wan-Sinn Y, Keng-Chong W, Choon-Sheen L. Comparative study of the volatile constituents of southeast asian Coffea arabica, Coffea liberica and Coffea robusta green beans and their antioxidant activities. J Essent Oil Bearing Plants. 2015;18:64-73.

16. Rubayiza A, Meurens M. Chemical discrimination of arabica and robusta coffees by Fourier transform Raman spectroscopy. J Agric Food Chem. 2005;53:4654-9. https://doi.org/10.1021/jf0478657.

17. Shrama H. A detail chemistry of coffee and its analysis. IntechOpen. 2020. https://doi.org/10.5772/intechopen.91725.

18. Lim D, Chang J, Ahn J, Kim J. Conflicting effects of coffee consumption on cardiovascular diseases: does coffee consumption aggravate pre-existing risk factors? Processes. 2020;8:438. https://doi. org/10.3390/pr8040438.

19. Godos J, Pluchinotta F, Marventano S, Buscemi S, Volti G, Galvano F, et al. Coffee components and cardiovascular risk: beneficial and detrimental effects. Int J Food Sci Nutr. 2014;65:92536. https://doi.org/10.3109/09637486.2014.940287.

20. Echeverri D, Montes FR, Cabrera M, Galán A, Prieto A. Caffeine's vascular mechanisms of action. Int J Vasc Med. 2010;2010: 834060. https://doi.org/10.1155/2010/834060.

21. Higashi Y. Coffee and endothelial function: a coffee paradox? Nutrients. 2019;11:2104. https://doi.org/10.3390/nu11092104.

22. Marx B, Scuvée É, Scuvée-Moreau J, Seutin V, Jouret F. Mechanisms of caffeine-induced diuresis. Med Sci. 2016;32:48590. https://doi.org/10.1051/medsci/20163205015.

23. Fenton R, Poulsen S, de la Mora CS, Soleimani M, Busslinger M, Rieg J, et al. Caffeine-induced diuresis and natriuresis is independent of renal tubular NHE3. Am J Physiol Ren Physiol. 2015;308: 1409-20. https://doi.org/10.1152/ajprenal.00129.2015.

24. Peerapen P, Ausakunpipat N, Sutthimethakorn S, Aluksanasuwan S, Vinaiphat A, Thongboonkerd V. Physiologic changes of urinary proteome by caffeine and excessive water intake. Clin Chem Lab Med. 2017;55:993-1002. https://doi.org/10.1515/cclm-2016-0464.

25. González S, Salazar N, Ruiz-Saavedra S, Gómez-Martín M, de Los R-GC, Gueimonde M. Long-term coffee consumption is associated with fecal microbial composition in humans. Nutrients. 2020;12: 1287. https://doi.org/10.3390/nu12051287. A study showing that habitual coffee consumption changes the composition of the gut microbiota.

26. Liu J, An N, Ma C, Li X, Zhang J, Zhu W, et al. Correlation analysis of intestinal flora with hypertension. Exp Ther Med. 2018;16:232530. https://doi.org/10.3892/etm.2018.6500.

27.• Torres-Callado L, Compañ-Gabucio L, González-Palacios S, Notario-Barandiaran L, Oncina-Cánovas A, Vioque J, et al. Coffee consumption and all-cause, cardiovascular, and cancer mortality in an adult Mediterranean population. Nutrients. 2021;13: 1241. https://doi.org/10.3390/nu13041241. A study showing that moderate coffee consumption is associated with lower allcause mortality and cancer after long follow-up. However, no significant association was found between coffee consumption and mortality from cardiovascular diseases.

28. Tverdal A, Selmer R, Cohen J, Thelle D. Coffee consumption and mortality from cardiovascular diseases and total mortality: does the brewing method matter? Eur J Prev Cardiol. 2020;27:1986-93. https://doi.org/10.1177/2047487320914443. A study showing a significant impact of the method of coffee preparation (filtered versus unfiltered brew) on the risk of death.

29. Grosso G, Micek A, Godos J, et al. Coffee consumption and risk of all-cause, cardiovascular, and cancer mortality in smokers and nonsmokers: a dose-response meta-analysis. Eur J Epidemiol. 2016;31: 1191-205. https://doi.org/10.1007/s10654-016-0202-2.

30. Teramoto M, Muraki I, Yamagishi K, Tamakoshi A, Iso H. Green tea and coffee consumption and all-cause mortality among persons with and without stroke or myocardial infarction. Stroke. 2021;52: 957-65. https://doi.org/10.1161/STROKEAHA.120.032273.

31. Cornelis M, El-Sohemy A, Kabagambe E, Campos H. Coffee, CYP1A2 genotype, and risk of myocardial infarction. JAMA. 2006;295:1135-41. https://doi.org/10.1001/jama.295.10.1135. 
32. Palatini P, Ceolotto G, Ragazzo F, et al. CYP1A2 genotype modifies the association between coffee intake and the risk of hypertension. J Hypertens. 2009;27:1594-601. https://doi.org/10.1097/ HJH.0b013e32832ba850.

33. Soares R, Schneider A, Valle S, Schenkel P. The influence of CYP1A2 genotype in the blood pressure response to caffeine ingestion is affected by physical activity status and caffeine consumption level. Vasc Pharmacol. 2018;106:67-73. https://doi.org/10. 1016/j.vph.2018.03.002.

34.• Zhou A, Hyppönen E. Long-term coffee consumption, caffeine metabolism genetics, and risk of cardiovascular disease: a prospective analysis of up to 347,077 individuals and 8368 cases. Am J Clin Nutr. 2019;109:509-16. https://doi.org/10.1093/ajen/nqy297. A study showing that the polymorphisms of the CYP1A2 gene (slower versus faster metabolism of caffeine) did not influence the observed effect of coffee consumption on the risk of cardiovascular disease.

35. Daneschvar H, Smetana G, Brindamour L, Bain P, Mukamal K. Impact of coffee consumption on physiological markers of cardiovascular risk: a systematic review. Am J Med. 2021;134:626-36. https://doi.org/10.1016/j.amjmed.2020.09.036.

36. Miranda A, Goulart A, Benseñor I, Lotufo P, Marchioni D. Coffee consumption and risk of hypertension: a prospective analysis in the cohort study. Clin Nutr. 2021;40:542-9. https://doi.org/10.1016/j. clnu.2020.05.052. Study showing that beneficial effect of moderate coffee intake (1-3 cups/day) on risk of hypertension was observed only in never smokers.

37. Ghavami H, Khoshtinat M, Sadeghi-Farah S, Kalimani A, Ferrie S, Faraji H. The relationship of coffee consumption and CVD risk factors in elderly patients with T2DM. BMC Cardiovasc Disord. 2021;21:241. https://doi.org/10.1186/s12872-021-02058-7. Study showing that coffee consumption in patients with type 2 diabetes significantly reduced diastolic blood pressure.

38.• Van Oort S, Beulens J, van Ballegooijen A, Grobbee D, Larsson S. Association of cardiovascular risk factors and lifestyle behaviors with hypertension: A Mendelian randomization study. Hypertension. 2020;76:1971-9. https://doi.org/10.1161/ HYPERTENSIONAHA.120.15761. Mendelian randomization study showing that coffee consumption was not significantly associated with the risk of hypertension.

39.• Kim J, Hoang T, Bu S, et al. Associations of dietary intake with cardiovascular disease, blood pressure, and lipid profile in the Korean population: a systematic review and meta-analysis. J Lipid Atheroscler. 2020;9:205-29. https://doi.org/10.12997/jla. 2020.9.1.205. Meta-analysis showing that coffee consumption significantly reduced the risk of hypertension.

40. D’Elia L, Fata E, Galletti F, Scalfi L, Strazzullo P. Coffee consumption and risk of hypertension: a dose-response meta-analysis of prospective studies. Eur J Nutr. 2019;58:271-80. https://doi.org/ 10.1007/s00394-017-1591-z.

41. Miranda A, Steluti J, Norde M, Fisberg R, Marchioni D. The association between genetic risk score and blood pressure is modified by coffee consumption: gene-diet interaction analysis in a population-based study. Clin Nutr. 2019;38:1721-8. https://doi. org/10.1016/j.clnu.2018.07.033.

42. Navarro A, Martinez-Gonzalez M, Gea A, Ramallal R, Ruiz-Canela $\mathrm{M}$, Toledo E. Coffee consumption and risk of hypertension in the SUN Project. Clin Nutr. 2019;38:389-97. https://doi.org/10.1016/j. clnu.2017.12.009.

43. Xie C, Cui L, Zhu J, Wang K, Sun N, Sun C. Coffee consumption and risk of hypertension: a systematic review and dose-response meta-analysis of cohort studies. J Hum Hypertens. 2018;32:8393. https://doi.org/10.1038/s41371-017-0007-0.

44. Poole R, Kennedy O, Roderick P, Fallowfield J, Hayes P, Parkes J. Coffee consumption and health: umbrella review of meta-analyses of multiple health outcomes. BMJ. 2017;359:j5024. https://doi.org/ 10.1136/bmj.j5024.

45. Grosso G, Micek A, Godoss J, et al. Long-term coffee consumption is associated with decreased incidence of new-onset hypertension: a dose-response meta-analysis. Nutrients. 2017;9:890. https://doi. org/10.3390/nu9080890.

46. Rhee J, Qin F, Hedlin H, et al. Coffee and caffeine consumption and the risk of hypertension in postmenopausal women. Am J Clin Nutr. 2016;103:210-7. https://doi.org/10.3945/ajen.115.120147.

47. Grosso G, Stepaniak U, Polak M, et al. Coffee consumption and risk of hypertension in the Polish arm of the HAPIEE cohort study. Eur J Clin Nutr. 2016;70:109-15. https://doi.org/10.1038/ejcn. 2015.119.

48. Steffen M, Kuhle C, Hensrud D, Erwin P, Murad M. The effect of coffee consumption on blood pressure and the development of hypertension: a systematic review and meta-analysis. J Hypertens. 2012;30:2245-54. https://doi.org/10.1097/HJH. 0b013e3283588d73.

49. Zhang Z, Hu G, Caballero B, Appel L, Chen L. Habitual coffee consumption and risk of hypertension: a systematic review and meta-analysis of prospective observational studies. Am J Clin Nutr. 2011;93:1212-9. https://doi.org/10.3945/ajcn.110.004044.

50. Noordzij M, Uiterwaal C, Arends L, Kok F, Grobbee D, Geleijnse $\mathrm{J}$. Blood pressure response to chronic intake of coffee and caffeine: a meta-analysis of randomized controlled trials. J Hypertens. 2005;23:921-8. https://doi.org/10.1097/01.hjh.0000166828. $94699.1 \mathrm{~d}$.

51. Winkelmayer WC, Stampfer MJ, Willett WC, Curhan GC. Habitual caffeine intake and the risk of hypertension in women. JAMA. 2005;294:2330-5. https://doi.org/10.1001/jama.294.18.2330.

52. Xu Z, Meng Q, Ge X, Zhuang R, Liu J, Liang X, et al. A short-term effect of caffeinated beverages on blood pressure: a meta-analysis of randomized controlled trails. J Funct Foods. 2021;81:104482. https://doi.org/10.1016/j.jff.2021.104482.

53. Zimmermann-Viehoff F, Thayer J, Koenig J, Herrmann C, Weber C, Deter H-C. Short-term effects of espresso coffee on heart rate variability and blood pressure in habitual and non-habitual coffee consumers-a randomized crossover study. Nutr Neurosci. 2016;19: 169-75. https://doi.org/10.1179/1476830515Y.0000000018.

54. Teng C, Lim W, Chua C, Teo R, Lin K, Yeo J. Does a single cup of caffeinated drink significantly increase blood pressure in young adults? A randomised controlled trial. Aust Fam Physician. 2016;45:65-8.

55. Hara A, Ohide H, Miyagawa K, et al. Acute effects of caffeine on blood pressure and heart rate in habitual and non-habitual coffee consumers: a randomized, double-blind, placebo-controlled study. Jpn J Pharm Health Care Sci. 2014;40:383-8.

56. Corti R, Binggeli C, Sudano I, et al. Coffee acutely increases sympathetic nerve activity and blood pressure independently of caffeine content: role of habitual versus nonhabitual drinking. Circulation. 2002;106:2935-40. https://doi.org/10.1161/01.cir.0000046228. 97025.3a

57. Mesas A, Leon-Muñoz L, Rodriguez-Artalejo F, Lopez-Garcia E. The effect of coffee on blood pressure and cardiovascular disease in hypertensive individuals: a systematic review and meta-analysis. Am J Clin Nutr. 2011;94:1113-26. https://doi.org/10.3945/ajcn. 111.016667.

58. Palatini P, Benetti E, Mos L, et al. Association of coffee consumption and CYP1A2 polymorphism with risk of impaired fasting glucose in hypertensive patients. Eur J Epidemiol. 2015;30:209-17. https://doi.org/10.1007/s10654-015-9990-z.

59. Palatini P, Fania C, Mos L, et al. Coffee consumption and risk of cardiovascular events in hypertensive patients. Results from the HARVEST. Int J Cardiol. 2016;212:131-7. https://doi.org/10. 1016/j.ijcard.2016.03.006. 
60.• Lopez-Garcia E, Orozco-Arbeláez E, Leon-Muñoz L, GuallarCastillon P, Graciani A, Banegas J, et al. Habitual coffee consumption and 24-h blood pressure control in older adults with hypertension. Clin Nutr. 2016;35:1457-63. https://doi.org/10.1016/j.clnu. 2016.03.021. Study showing that coffee consumption did not influence on the risk of uncontrolled blood pressure in hypertensive patients who had never smoked.

61. Guessous I, Eap C, Bochud M. Blood pressure in relation to coffee and caffeine consumption. Curr Hypertens Rep. 2014;16:468. https://doi.org/10.1007/s1 1906-014-0468-2.

62. Renda G, Zimarino M, Antonucci I, et al. Genetic determinants of blood pressure responses to caffeine drinking. Am J Clin Nutr. 2012;95:241-8. https://doi.org/10.3945/ajcn.111.018267.

63. Palatini P, Ceolotto G, Ragazzo F, et al. CYP1A2 genotype modifies the association between coffee intake and the risk of hypertension. J Hypertens. 2009;27:1594-601. https://doi.org/10.1097/ HJH.0b013e32832ba850.

64. Karabegović I, Portilla-Fernandez E, Li Y, et al. Epigenome-wide association meta-analysis of DNA methylation with coffee and tea consumption. Nat Commun. 2021;12:2830. https://doi.org/10. 1038/s41467-021-22752-6.

65. Ek W, Tobi E, Ahsan M, et al. Tea and coffee consumption in relation to DNA methylation in four European cohorts. Hum Mol Genet. 2017;26:3221-31. https://doi.org/10.1093/hmg/ddx194.

66. Narkiewicz K, Maraglino G, Biasion T, Rossi G, Sanzuol F, Palatini P. Interactive effect of cigarettes and coffee on daytime systolic blood pressure in patients with mild essential hypertension. HARVEST Study Group (Italy). Hypertension Ambulatory Recording VEnetia STudy. J Hypertens. 1995;13:965-70. https:// doi.org/10.1097/00004872-199509000-00005.
67. Unger $\mathrm{T}$, Borghi $\mathrm{C}$, Charchar F, et al. 2020 International Society of Hypertension Global Hypertension Practice Guidelines. Hypertension. 2020;75:1334-57. https://doi.org/10.1161/ HYPERTENSIONAHA.120.15026.

68. Tykarski A, Januszewicz A, Filipiak KJ, et al. Zasady postępowania w nadciśnieniu tętniczym - 2019 rok. Wytyczne Polskiego Towarzystwa Nadciśnienia Tętniczego. Nadciśnienie Tętnicze w Praktyce. 2019;5:1-86 [article in Polish].

69. Tykarski A, Filipiak KJ, Januszewicz A, et al. 2019 Guidelines for the Management of Hypertension - Part 1-7. Arterial Hypertension. 2019;23:41-87. https://doi.org/10.5603/AH.a2019.0008

70. Tykarski A, Filipiak KJ, Januszewicz A, et al. 2019 Guidelines for the Management of Hypertension - Part 8-9. Arterial Hypertension. 2019;23:203-239. https://doi.org/10.5603/AH.a2019.0021

71. Williams B, Mancia G, Spiering W, et al. 2018 ESC/ESH Guidelines for the management of arterial hypertension: the Task Force for the management of arterial hypertension of the European Society of Cardiology (ESC) and the European Society of Hypertension (ESH). Eur Heart J. 2018;39:3021-104. https://doi. org/10.1093/eurheartj/ehy339.

72. Whelton P, Carey R, Aronow W, et al. 2017 ACC/AHA/AAPA/ ABC/ACPM/AGS/APhA/ASH/ASPC/NMA/PCNA Guideline for the prevention, detection, evaluation, and management of high blood pressure in adults: a report of the American College of Cardiology/American Heart Association Task Force on Clinical Practice Guidelines. Circulation. 2018;138:484-594. https://doi. org/10.1161/CIR.0000000000000596.

Publisher's Note Springer Nature remains neutral with regard to jurisdictional claims in published maps and institutional affiliations. 